\title{
Gymnastics between Protestantism and Libertinism from 1880 to 1940: A Comparative Analysis of Two Internation- ally Renowned Danish Gymnastics Educators
}

\author{
Hans Bonde
}

\begin{abstract}
The purpose of this article is to analyze and compare two internationally renowned Danish Gymnastics teachers, Jørgen Peter Muller and Niels Bukh. Whereas Muller's home gymnastics had a cosmopolitan agenda that appealed to everyone regardless of ethnic origin, including many Jews, Bukh's gymnastics increasingly became embedded in a right-wing nationalist frame of reference. Muller created an individual system of home gymnastics with a focus on health by means of exercises and the cleansing of the body that included a cold shower. In contrast, Bukh's system was a collective form of gymnastics that emphasised the beauty of the young body. Common to both of them, however, was propagation of sexual liberation, which in Muller's case focused on the naked heterosexual body's manifestations in the sunlight and the fresh air. By contrast, Bukh was homosexual and through his aesthetic gaze he encouraged well-trained and sweaty young men to show their muscular upper body in touch-tight choreographies wearing only boxer shorts. It is the main thesis of the article that the contribution of sport to sexual liberation from late Victorianism's firm grip is far greater than hitherto assumed.
\end{abstract}

Keywords • gymnastics, sports, hygiene, aesthetics, sexuality

\section{Introduction}

In this article, I will conduct a comparative analysis of two world-renowned Danish gymnastics teachers J.P. Muller (1866-1938) and Niels Bukh (1880-1950). The fundamental research question is to what extent and in what way they contributed to the sexual liberation of the male body in opposition to the strict notions of appropriate sexual behaviour of their contemporaries. It is my thesis that the apparent innocence of gymnastics and its rational attachment to health care has made it a suitable place for an increased nudity and more sensual movements. First, a presentation of the two main characters of the article is necessary.

J.P. Muller became a propagandist for the blessings of water, air and light at a time when these concepts were gaining an increasingly important role in the emerging science of medicine. He spread the evolving medical profession's gospel of hygiene and purification to the broad public by his own example and his simple ritualistic scheme of gymnastics. In his writings and in his agitation he always fought against the cramped life of the growing cities and for the blessings of the open-air life which made him become an icon of beauty and health for the evolving Continental movements which praised the concepts of nudity, healthy food and the liberation of the body from Victorian dogmatism. In 1908 he published a book on sexology that was a contribution to sexual liberation and feminism. In 1912 Muller had achieved such international recognition that he was able to settle in London.

Hans Bonde is Professor in Sports History at the Department of Nutrition, Exercise and Sports, University of Copenhagen, Denmark.

Email:hbonde@nexs.ku.dk

Nordic Journal of Educational History 2017. ( $)$ Hans Bonde. This is an Open Access article distributed under the terms of the Creative Commons CC-BY4.0 License (http://creativecommons.org/licenses/by/4.0/). 
In 1920, Niels Bukh replaced J.P. Muller as the great Danish gymnastics educator of international stature. His revolutionising concept of gymnastics for young Danish male farmers mainly gained its fame through its effects on masculinity regarding norms for touching other men, for the rhythmic expression of the male body and for the exposure of the naked and sensual young bodies. These features of Bukh's gymnastics broke with existing norms for the disciplined and correct male demeanour in the inter-war period, though a general celebration of the athletic and partly nude male body was becoming more accepted in many European countries.

In addition, it is difficult to understand the popularity of Bukh's new gymnastics for the male heterosexual youth without including his own homosexual orientation and personal interest in the aesthetics of the male body. The great paradox of the life of Niels Bukh is that he created a liberating male gymnastics but, as we shall see, tried to use it for totalitarian purposes.

In the following gymnastics is defined as a movement culture that aims at improving the level of physical excellence for the purpose of health and beauty. ${ }^{1}$ Gymnastics can be "sportified" in the sense that it is performed for competition in accordance with an "objective" system of measurement. This article constitutes a traditional historical study based on source criticism. The source material for this article mainly consists of Muller's extensive writings, interviews with J.P. Muller's descendants and pupils, photographs from his many books and the film, from 1911, of Muller showing his gymnastics system made by Danish Royal photographer Peter Elfeldt. ${ }^{2}$ As far as Niels Bukh is concerned, Niels Bukh's own archive from his gymnastics college is supplemented by archive material from the Danish Ministry for Foreign Affairs together with a wide range of interviews with Bukh's family and students from Bukh's own time.

As far as previous research is concerned, I have written several research articles and books on the topic. In particular, three articles constitute the backbone of the present article, ${ }^{3}$ which, on the other hand, derives its originality from a comparison between the two Danish gymnastic teachers and especially the underlying erotic dimension. The article, however, takes its starting point from Michel Foucault's notion that sometimes sexuality is very present where it is least expected to be expressed and, in addition, that the apparent innocence of a phenomenon such as gymnastics could function as a shield hiding the sensuous nature of activities. ${ }^{4}$ Furthermore, I have been inspired by the Danish sociologist Henning Bech, who claims that the strong denial of the presence of a phenomenon such as male homosexuality in the culture of modern competitive sport can sometimes be an indication of homoerotic

1 See Jacques Defrance, L'excellence Corporelle - La Formation des Activités Physiques et Sportives Modernes (1770-1914) (Rennes: Press universitaires de Rennes, 1987).

2 The film can be studied at: http://www.dfi.dk/faktaomfilm/film/da/48886.aspx?id=48886 [accessed November 30, 2017).

3 Hans Bonde, "From Hygiene to Salvation: J.P. Muller, International Advocate of Gymnastics," International Journal of the History of Sport 26, no. 10 (2009), 1357-375; Hans Bonde, "Niels Bukh's Gymnastics School in Denmark, 1912-1933: Gymnastics, Erotics, and Male Bonding," International Journal of the History of Sport 32, no. 6 (2015): 800-14; Hans Bonde, "The struggle for Danish Youth: Fascism, Sport, Democracy," International Journal of the History of Sport 26, no. 10 (2009), $1436-457$.

4 Michel Foucault, The History of Sexuality, Vol. 1: The Will to Knowledge (London: Allen Lane, 1976). 
undercurrents: "Where homoerotism is unthinkable it might be the most."5 Or to be more specific, the high degree of closeness, affections ${ }^{6}$ and intimacy in modern sport sometimes creates a need to reassure in a demonstrative way that this has nothing to do with homosexuality.

In addition, Allen Guttmann's book The Erotic in Sport has been inspirational. ${ }^{8}$ Guttmann shows that sport often has an underlying erotic dimension that thrives especially if it is not expressed in a conscious way. For him, eroticism in sports is usually not the main characteristic, but often an important bi-phenomenon of sport. He believes that sport can create erotic feelings both through the actual sensations and touches of the athletes, but also through the enthusiasm of spectators by watching the movements of the often beautiful and well-trained athletic bodies in rhythmic action. For him, the driving force of becoming fit often is connected to the desire of creating a sexually attractive body in your own eyes and the eyes of the others. ${ }^{9}$

The erotic dimension of sport has traditionally been a taboo in modern history. Typically, the reaction of the public in J.P. Muller's case was that though he fought for nudity and self-massage, his propagation of extreme outdoor sporting activities in fresh air followed by a cold shower was, on the contrary, a protection against sexual licentiousness. Off course, Bukh and Muller did not invent the celebration of the male athletic body from around 1900 and onwards. Rather they contributed to a much larger movement which has been labelled "vitalism." Apart from being a philosophical current with inspiration from among others Friedrich Nietzsche, vitalism in addition was expressed artistically in Western Europe from around 1900 to 1914. In Denmark a painter such as J.F. Willumsen celebrated life's light, youthful and active elements. The Danish writer Johannes V. Jensen (Nobel prize winner in 1944), was strongly oriented towards an American inspired praise of outdoor life, and in a philosophy concentrated in an aphorism, notoriously famous in Denmark, as "the strong ones' right to the realm."10 The celebration of the male body was also to be found in Sweden. The Swedish scholar Patrik Steorn has discovered that in Sweden the "use of images of naked men was widespread at the turn of the 20th century" in art, photographs, newspaper and advertising. ${ }^{11}$

In addition, my investigation will include religious currents not least in J.P. Muller's gymnastics and his concept of "hardening of the body" which I interpret in the light of research in British Muscular Christianity which was of inspiration to him. The concept of Muscular Christianity will be defined below. Concerning the term nationalism, I will use it in the sense of the political scientist and historian Benedict Anderson's theory on nations as "imagined communities," and that unifying histori-

5 Henning Bech, When Men Meet: Homosexuality and Modernity (Cambridge: Polity Press, 1997).

6 Lone Friis Thing, Sport - en emotionel affore: Kvinder, holdsport og aggression (Copenhagen: Copenhagen University, 1999).

7 Frederik Schoug, Intima samhällsvisioner (Stockholm: Symposion, 1997).

8 Allan Guttmann, The Erotic in Sport (Columbia: University Press, 1996), 2-3.

9 Guttman (1996), 3.

10 Johannes V. Jensen in the poem “Tilegnelse," Skovene (Copenhagen: s.n., 1904).

11 See Patrik Steorn, Nakna män: Maskulinitet och kreativitet i svensk bildkultur 1900-1915 (Stockholm: Norstedts Akademiska Förlag 2006), 228. 
cal symbols are at the core of modern nation building. ${ }^{12}$ Especially, Bukh's attempt to reconcile his Danish national sentiments with National Socialism will be discussed.

Finally, I use the term Libertinism not as an expression of a total rejection of all sexual moral but rather as a term which signifies the attempt to expand existing sexual possibilities in a given context. In this sense J.P. Muller's agitation for sex before marriage and the use of contraception can be seen as containing libertine elements although he also condemned homosexuality as a perversion and rejected adultery and promiscuity. ${ }^{13}$

\section{The success of J.P. Muller}

The typical office worker in big cities is often a sad sight. Hunched over in early years, his shoulders and hips made crooked by the awkward position at his desk, his face pale, pimply, and powdered, his thin neck sticking out of a collar that a normal man could use as a cuff, his foppish, fashionable suit rotating around pipe cleaners that are supposed to be arms. ${ }^{14}$

In 1904 at the age of 39 a Dane, Lieutenant J.P. Muller (1866-1938), wrote a book called My System. Its main theme was home gymnastics, and in five months 30,000 copies were sold. This figure acquires additional significance, when one bears in mind the small size of Denmark with its 2.5 million inhabitants. In one year 20,000 copies were published in Swedish, 70,000 in German and more than 25,000 in English. 21,000 copies were to be published in the USA, 11,000 each in France, Czechoslovakia and the Netherlands and 6,000 in Finland. This explosive sale in a single year was followed by steady growth; by 1930 J.P. Muller's books had been translated into 26 languages and sold 1.5 million copies. One million copies were claimed to be sold alone in English-speaking countries. ${ }^{15}$ In the following years Muller established himself as an author by publishing, in 1908, The Fresh Air Book, in 1912 My System for Ladies and my System for Children, in 1914 My Breathing System, in 1915 My Army and Navy System, in 1923 The Daily Five Minutes and in 1927 My Sun-Bathing and Fresh-Air System, to mention only the English editions. My System and his many other writings on gymnastics and hygiene remained important right up to 1930.

After the great international breakthrough with My System, Muller busied himself abroad showing how strengthening his system was. As an agitator he was unsurpassed-for example when he had a wheelbarrow loaded with stones run over a board on his stomach so that he could demonstrate his bulging abdominal muscles. More than anyone, Muller became Denmark's great apostle of health.

In 1912, Muller had achieved such international recognition that he was able to settle in London, change his name from Müller to Muller, and open the very successful Muller Institute at 45, Dover Street, Piccadilly. Muller became principal with "a lady director, secretaries and a staff of trained instructors of both sexes under his direct supervision." ${ }^{16}$ His institute was frequented by ailing members of the affluent

12 Benedict Anderson, Imagined Communities: Reflections on the Origin and Spread of Nationalism (London: Verso, 2006).

13 J.P. Muller, Kønsmoral og livslykke (Copenhagen: s.n., 1908), 296, passim.

14 J.P. Muller, Mit System (Copenhagen: Jul. Gjellerups Forlag, 1904), 31.

15 See J.P. Muller, My System (London: David McKay Publisher, 1905), passim. 50; J.P. Muller, Mirakel-Kure (Copenhagen: s.n., 1934), 11.

16 J.P. Muller, My Breathing System (London: s.n., 1914), 95. 
classes, including the Prince of Wales, later King Edward VIII (1894-1972). In 1925 the Prince of Wales granted his patronage to Muller's books. ${ }^{17}$ Muller also contributed to Danish National identity and to the image of Denmark abroad. In Dansk biogragisk håndleksikon (Danish Bibliographical Hand Dictionary) of 1923 it was said that Muller had "more than any other existing person made the name of Denmark famous. His name is mentioned from Piccadilly to the Far East, and many people greet him as the great health apostle of our times." ${ }^{18}$

The success of Muller's system was partly due to the fact that it could be carried out without special apparatus. Only an ordinary hand wash basin and jug were needed. This meant that virtually everybody could afford to practise the system. Mysystem was also distinguishable from many other books of the same type by the fact that the exercises were calculated to be performed in a specific, short space of time-a fact that meant a great deal "to the busy, hurrying, average man" of modern society. ${ }^{19}$ Finally, Muller's system was a stimulating exercise in synthesis, whereas most systems of home gymnastics had focused on one or two sources of health. Muller's system combined gymnastics with a daily bath, fresh air, sunlight and the preservation of the skin through rubbing exercises.

Muller's praise of the naked body was inspired by the German Life Reform-movement. ${ }^{20}$ He travelled to Germany, Switzerland and Austria several times from 19061910, where his ideas found fertile ground among similar minded men. The praise of the naked body, of the sun and of nature itself was prevalent among the many "nature healers" such as the Swiss Arnold Rikli who Muller credit for having established the first "open air sanatorium in the year $1855 .{ }^{21}$

In addition, Muller's concept of the fit and athletic body was inspired by the creator of modern body building, Eugene Sandow, who organised some of first body building contests in London in 1901. ${ }^{22}$ However, whereas Sandow praised the building of a muscular body, Muller was much more preoccupied with health obtained by a clean skin and healthy internal organs. In this way it could be stated that Sandow paved the way for body building whereas Muller paved the way for the health oriented fitness movement.

\section{Masculine beauty}

Already in the late nineteenth century, Muller was known to the Danish public as the epitome of the new, vital man: on the one hand, as one of the brothers in the conquering 'Muller team' that dominated the sport of rowing; and, on the other, as a health agitator in the press, and for his great versatility in sports as varied as boxing, race-walking and rowing. Before 1900 he could boast Danish records in a whole

17 J.P Muller, My Sun-Bathing and Fresh-Air System (London: Athletic Publications 1927), 15.

18 Dansk biografisk håndleksikon (Copenhagen: Gyldendals Boghandel and Nordisk,, 1923), 672-75.

19 Katholische Schulzeitung, 16 June 1905. Quoted from How J.P. Muller and 'My system' are Spoken of by Officers, Doctors, Gymnastic Instructors, Schoolmasters and Others, and by Newspapers and Magazines Outside Denmark (London/Copenhagen: s.n., 1905), 16.

20 J.P. Muller, Vink om Sundhedsrøgt og Idrat (Copenhagen: Tillges Boghandel 1907), passim.

21 Karl Rothschuh, "From the history of the naturopathic movement (VII). Healing power of light, air and earth. Arnold Rikli, Adolf Just and Pastor Felke," Zeitschrift für Allgemeinmedizin 16 (1983), 933-40.

22 David Chapman, Sandow the Magnificent (Urbana: University of Illinois, 1994), 132-35. 
succession of athletic disciplines such as running, discus and hammer throwing. From around 1885 to 1900 he became more preoccupied with all different sorts of sports and became known as the pioneering "Mr. Sport" of the early Danish sports movement.

J.P. Muller was the son of a clergyman, one of his brothers became clergymen as well, and he himself studied theology for a couple of years obtaining a bachelor degree. His almost manic devotion to hard training can be interpreted a compromise between the tradition of asceticism of his childhood home and the celebration of the body of early modern sport. ${ }^{23}$ After his athletic career, J.P. Muller wanted to stay fit but had no opportunity of participating in sport on a regular basis. Therefore, he started to develop a gymnastics system that would make it possible to retain one's good health and vigour without being too time-consuming. The result was the book My System. The English deluxe edition contained 44 photographic illustrations; and a chart illustrating the exercises mounted on cardboard could be procured through any British bookseller. In all of the photographs Muller himself showed the exercises either half-naked or even a few times totally naked. In his books Muller was celebrated as one of the most handsome men of his times. ${ }^{24}$

Reviews of his books commented on his extraordinarily well-built body, which was seen as a proof of the validity of My System. For instance, the German Monatsschrift für das Turnwesen (Monthly Gymnastic Review) wrote: "If the pictorial illustrations of the author's own superb physical proportions were not proof enough, his style would reveal that we have here to do with a man who does not treat us to empty theory but to actual fact, who is a living example of what he preaches." ${ }^{25}$ The many pictures and the fresh style made it easy to identify with Muller, and My System suggested that following the system would reshape one's body to the ideal of the master himself.

As part of Muller's vitalist stimulus, he was inspired by antiquity. Even his image of male beauty was neoclassical in inspiration and consequently the first page of $M y$ System was illustrated by a photograph of a statue by the Greek sculptor Lysippos. This marble statue was called Apoxyomenos (the scraper) and the choice of this motif was no coincidence. Muller commented:

\footnotetext{
Much has been written about this statue, but all concur in praising its beauty, and in admiring the Greeks, who, by means of their athletic sports and gymnastic training, were able to produce human forms fit to serve as models for such sculptures.

I have expressly chosen Apoxyomenos from among the many beautiful statues of antiquity to decorate the cover of my book because he is the embodiment of the contents of it: He is the athlete cleansing and caring for his skin after exercise, and thus the ideal towards which my book points. Under this pseudonym, generally abbreviated to Apox or Ap, I wrote for a number of years on Athletics [in the press]. ${ }^{26}$
}

23 Max Weber's notion that the protestant ethics was used to form new citizens devoted to labour and hard work in early capitalist society could in addition be applied to the sports movement which praised hard training as a means to victory, see: Hans Bonde, "Den sportslige askese: Om den protestantiske etik og sportens ånd," Fønix 26, no. 3 (2002), 167-74; Max Weber, The Protestant Ethic and the Spirit of Capitalism (London and Boston: Unwin Hyman, 1930).

24 Muller (1905).

25 Bonde (2002), 20.

26 Muller (1905), 148. 
Muller claimed that for many years he had trained with the ideal of Apoxyomenos in mind. Therefore, he sharply criticised the traditional ideal of the dominant so-called Swedish or Ling gymnastics, which could be summed up as: 'stomach in, chest out.' One should here bear in mind that Ling Gymnastics around 1900 were widespread in the educational and military systems of many countries on a worldwide scale. As an example Swedish gymnastics had gained a foothold in the British Army, Navy and school system. ${ }^{27}$ Muller certainly knew that paving the way for his own system implied a critique of Swedish gymnastics:

\begin{abstract}
The front line of a healthy man, seen in profile, will be almost even, and show the chest and abdomen as being equally forward; only during exhalation will the abdomen protrude a little. God made man in this shape. And thus was His masterpiece reproduced by the unparalleled sculptors of antique Hellas. In the statues of ancient Greek athletes and demigods, we never find the tightly indrawn abdomen and outward arched chest, so common nowadays. Why? Because it is unnatural, inexpedient, and therefore not aesthetic. $^{28}$
\end{abstract}

In 1921 Muller tried to persuade the Danish Ministry of Education to introduce his system in the Danish primary and lower secondary schools. The Ministry responded to this by informing all schools that Muller's system could be integrated into the gymnastic lessons if wished for by the teacher. Muller, however, was sceptical of the impact of this step and therefore sharply criticised the Ministry of Education. After all, the head of Danish school gymnastics, K.A. Knudsen, who really had the power to make Muller's dream come true, was a fanatical devotee of Swedish/Ling gymnastics, and thus probably worked against Muller's plans. ${ }^{29}$

Muller's criticism of traditional gymnastics paved the way for the ideal of a more relaxed male body. In the sports movement at the turn of the century the ideal of the tense male body was widespread. For instance, this ideal was very dominant in the first beauty contests for men in Denmark, organised by the Dansk Athlet Union for weightlifting, boxing and wrestling, which took place between 1902 and 1917 in Copenhagen. ${ }^{30}$ Notions that in modern bourgeois culture women have always been the aestheticised and sexualised gender are thus mistaken: the first beauty contests in Denmark were in fact for men.

Muller participated in the 'beauty contest' of 1903 and won. The choice of Muller instead of one of the strong "body-builders" certainly wasn't unaffected by the fact that the referees belonged to the same social class as Lieutenant Muller, who as mentioned had also studied theology at the University of Copenhagen. They were either medical doctors or sculptors and presumably preferred a less "vulgar," muscle-bound and demonstrative form of masculinity. However, with regard to the mas-

27 Muller (1914); J.P Muller, My Army and Navy System of Free-standing Exercises: A Manual of Physical Training for Soldiers, Sailors, Constables and Others (London: s.n., 1915), 17-20.

28 J.P. Muller, The Daily Five Minutes (London: s.n., 1923), 27.

29 Anne Lykke Poulsen, Den kvindelige kvinde (Copenhagen: Institut for Idræt, Københavns Universitet, 2005), 52-55; J.P. Muller, What is Wrong with the Physical Education of our Children (Copenhagen: s.n., 1927), passim.

30 Hans Bonde, "Vitalist Sport," in The Spirit of Vitalism: Health, Beauty and Strength in Danish Art, 1890-1940, ed. G. Hvidberg Hansen and G. Oelsner (Copenhagen: Museum Tusculanum Press, 2011), 88-105. 
culine erotic ideal of the broad chest and the small hips, ${ }^{31}$ Muller's ideal came very close to that of the working-class sportsmen. ${ }^{32}$

The great success of My System must be attributed partly to the fact that in a narrow, post-Victorian culture Muller dared to perform more or less naked in front of an audience and in photographs. Thus, Muller's books and displays could play a role as sexually stimulating but at the same time shielded by an aura of health, hygiene and naturalness. The appeal of a naked body to a person who most probably had never seen his own parents without clothes is not to be underestimated. However, in My System for Ladies from 1912 the female gymnast wore a bathing suit that covered almost the whole of her body. ${ }^{33}$ Muller's books, his public displays of My System and the Danish beauty contests for men bear witness to the existence of a segregated cult of the nude male, at least in Denmark after the turn of the century. The nude female body was unacceptable in the media, probably because female nakedness was strongly associated with eroticism and pornography.

Another reason for Muller's success was that his gymnastics was open to all, while many other gymnastics systems became more and nationalistic and even racially based as it happened to some extent in Germany. This cosmopolitan aspect probably forms the background for many Jews' fascination with Muller's system of whom not least Franz Kafka stands out. ${ }^{34}$

\section{The purification of mankind}

The gist of Muller's philosophy was the importance of preventing illness through a process of cleansing the body. As already shown, Muller's ideal was the Apoxyomenos of Lysippos, not only because of Apoxyomenos' beauty, but to a high degree also because of his actions, "cleansing himself with a bronze scraper, after athletic exercises from oil, sweat and dust." ${ }^{35}$ Unlike other systems of home gymnastics, Muller's system placed the bath in the middle of the exercises after the traditional exercises of bending and stretching and before his unique rubbing exercises. ${ }^{36}$ However, Muller also widened the meaning of the word bath, so that every part of his system became part of the process of cleansing. The central idea of the open window during the exercises was meant as an 'air-bath.' The best place to exercise was outside in sunny weather, which Muller called 'air-bathing.' Muller also recommended not wearing hats, calling this wearing a 'hat of air.' To lie in bed without clothes was called wearing an 'air nightdress,' and so forth. ${ }^{37}$

Muller became an apostle of the fresh air movement, which found many supporters after the turn of the century. In Germany, Austria and Switzerland he became a

31 Muller, (1927), 112.

32 Hans Bonde, “The Time and Speed Ideology: 19th Century Industrialisation and Sport," International Journal of the History of Sport 26, no. 10 (2009), 1315-334.

33 J.P Muller, My System for Ladies: Fifteen Minutes' Exercise a Day for Health's Sake (Philadelphia, D. McKay, 1915).

34 Mark Anderson, Kafka's Clothes: Ornament and Aestheticism in the Habsburg Fin de Siècle (Oxford: Oxford University Press, 1995).

35 Muller (1905), 2.

36 See Peter Elfeldt's film from 1911 of Muller demonstrating his system, http://www.danskkulturarv. dk/dr/gymnastik-i-1908/ (accessed November 30, 2017).

37 Muller (1927). 
symbol for the members of the Wandervogel, or hiking, movement and the emergin light and air bath institutions. In Germany there was actually a phrase, zu Mullern, that is to engage in his rubbing exercises, a kind of 'auto-physiotherapy'. Muller's central idea, which found broad recognition, was that gymnastics in particular and hygiene in general had the purpose of cleansing and strengthening the 'inner body' with the help of fresh air, clean water and sunlight. Muller's gymnastic exercises were meant to increase the metabolism of the body, whereby the body would be cleansed from all the poisonous substances that, if not removed, would accumulate in the internal organs. ${ }^{38}$

Muller's unique rubbing exercises (Figure 1) meant that people developed a growing awareness of, and identification with, their skin. Muller described the various phases and techniques of the bath in detail, which illustrates that many people did not know how to have a bath at that time. Every day, he said, one should rub one's skin, and ten of his eighteen exercises were rubbing exercises either with the hand or after the bath with a towel. The rubbing exercises basically were a form of skin gymnastics which aimed at removing all of the old exhalations of the body and increasing the circulation of the blood and thereby the metabolism of the body.

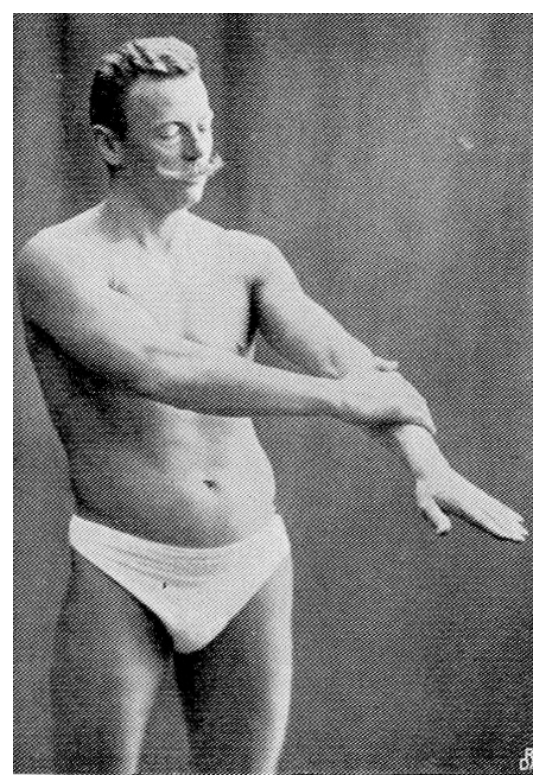

Figure 1. J.P. Muller performing his rubbing exercises. Source: J.P Muller, My System (London: David McKay Publisher, 1905).

According to Muller, neither money nor status was the real mark of distinction but having a clean, decent and healthy body. For Muller the central 'organ' of the human body was the skin. Muller always described dirty skin in the most disgusting manner. In a description of unclean sportsmen Muller stated: "The pores of their skin were choked with clotted grease and dirt until they could not perspire, while their muddy complexions or flabby appearance were infallible signs of their unwholesome condition." ${ }^{39}$ Muller's negative attitude towards unclean skin was based on the never-proven theory that the dirt of the body consists of waste matter and poisonous

38 Muller (1915).

39 Muller (1914), 25. 
substances which are given off through the skin and, if not removed every day, can be partially absorbed again to poison the body. In the long run the dirt that was not removed would result in the "hygienic breakdown" of the unclean person. ${ }^{40}$ This theory was propagated by many medical doctors though it came under attack after 1900 because of the growing understanding of bacteriology. Also, Muller's fascination with the healing power of the sun was inspired by medicine or, more accurately, by the creator of "light therapy," the Dane Niels Finsen, who received the Nobel Prize in medicine in 1903 for his discoveries.

The risk of poisoning the body, more than any other medical theory, could persuade people to have their daily bath and do their home gymnastics. Muller described the threatening bacilli in the most frightening way. Whereas in the past wolves, wild boars and robbers were the worst enemies, the "mortal enemies" of mankind now were said to be "the bacilli lurking in every corner." Clean water, soap and exercises had to replace "the sword and the spear" as the main weapons in man's fight against his enemies. ${ }^{41}$

In order to detect the degree of civilisation of a person, not the look of the clothes, but the smell of the skin became the central issue of Muller's systems. In this respect the nose replaced the eyes as the central "social sense."42 Muller's theory that the body perspiration was poisonous meant that the unclean person not only "polluted" himself but also all other persons nearby, almost just as passive smoking is considered by modern medical thinking today. Muller, therefore, often agitated for the open window in offices, railway compartments and so forth. The smell of sterility became the most acceptable smell of all. Every old, personal smell was abandoned, and to allow such a personal smell was objectionable "to those others whose sense of smell has not been blunted by an unhealthy mode of life." ${ }^{43}$

Whereas in other times and cultures smell had often been a central way of perceiving a person, the nose now became the central filter, allowing no personal odour to pass. Muller's perception of the polluting effect of the odours of the body seems to have been inspired by the popular theory in the nineteenth century called the miasmatic theory of disease. Diseases even as dangerous as the plague or cholera were perceived as being caused by a certain form of "bad air" or miasma - which is Greek for pollution. Today this theory has been replaced by the germ theory of disease. ${ }^{44}$

Muller's ideas of the importance of the clean skin were inspired by a general shift in nineteenth century European cultural history. As the French historian Georges Vigarello has demonstrated, traditionally in aristocratic culture it was important to keep up appearances by impressive cloths and the use of strong perfumes. In the words of Elizabeth Collingham in Imperial Bodies writing on the cleaning habits in London around 1800: "Cleanliness at the turn of the century was generally associated with clean linen rather than a spotless skin." 45

$\overline{40 \text { Muller (1914), } 23 .}$

41 J.P. Muller (1907), 265. This book is a collection of some of Muller's newspaper articles.

42 See, for instance Muller (1914), 16-19.

43 Muller (1905), 23.

44 Alain Corbin, The Foul and the Fragrant: Odor and the French Social Imagination (Cambridge: Harvard University Press, 1986).

45 Elizabeth Collingham, Imperial Bodies: The Physical Existence of the Raj, c. 1800-1947 (Cambridge: Polity Press, 2001), 46. 
However, during the early nineteenth century in France as in many other Western European countries, the bourgeoisie increasingly became interested in the hidden aspects of life and started the practice of taking a daily bath, emphasising a clean body and neutral, antiseptic odours. ${ }^{46}$ Health now presided over aesthetics and clean skin more and more became a demarcation line between the individuals of bourgeois culture that became strongly preoccupied with the taboos surrounding all the fluids of the body. ${ }^{47}$ The absence of odour in the intimate sphere now became a sign of class and good manners. ${ }^{48}$ In this way the civilisation of the body became an important factor in creating the modern individualistic man with a clear sense of body limits.

Like other gymnastic systems around the turn of the century, Muller's system had health as its basic assumption. Gymnastics per se aimed at preventing or curing ailments, and thus the subtitle of My System was "15 Minute's work a Day for Health's Sake." Muller was aware that illness had very severe social implications, since the "race" as a whole was "degenerating." ${ }^{49}$ It should be noted that 'race' in the Danish context was not understood in a racial or biological meaning of the word-as increasingly became the custom in Germany after 1900-but just as "the human race," not distinguishing between inhabitants in Denmark as "authentic population," Jews, Polish people (of whom many worked in Southern Denmark on the islands of Lolland and Falster) and so forth. ${ }^{50}$

For Muller the process of hardening the body through the daily bath and allround daily exercise was not only the individual's obligation towards himself but also towards society as a whole, since all other members of society had to pay for the sick person's reduced working capacity and the expensive health services. ${ }^{51}$ The cleansing and hardening of the body was also part of the creation of a new man by means of character building. The idea of stimulating the character of the young men from the countryside was inspired by the various sports imported from the UK. In the UK, sports were associated with the development of a form of protestant ethics. At many English public schools in the mid-eighteenth century the upper-class boys and young men were taught to put more emphasis on sports than on the academic subjects in order to build "character," that is to become hard, learn to never say die, and to be able to accept a defeat. ${ }^{52}$

Through "muscular Christianity" the young British men were supposed to obtain the hardship and willpower that qualified them to manage the development of capitalism and the leadership of the great empire. At the boarding school Rugby the new "sports religion" was developed by the chancellor Thomas Arnold Rugby, who led the school from 1828 to 1842 , and his message was diffused through Thom-

46 Georges Vigarello, Concepts of Cleanliness: Changing Attitudes in France since the Middle Ages (Cambridge: Cambridge University Press, 1988).

47 Norbert Elias, The Civilizing Process, Vol. I: The History of Manners (Oxford: Blackwell, 1969); Norbert Elias, The Civilizing Process, Vol. II: State Formation and Civilization (Oxford: Blackwell, 1982).

48 Corbin (1986).

49 See for instance Muller (1905), passim.

50 Lene Koch, Racehygiejne i Danmark 1920-56 (Copenhagen: Gyldendal, 1996), passim.

51 Muller (1905), 6.

52 James Anthony Mangan, Athleticism in the Victorian and Edwardian Public School (Cambridge: Cambridge University Press, 1981). 
as Hughes' novel Tom Brown's school days from $1857 \cdot{ }^{53}$ Muller was well acquainted with Tom Brown's School Days, which he mentioned as "this excellent book," and he recommended it to his readers, stating that "it is available in a very cheap version in Danish." 54

Through the inspiration from muscular Christianity, Muller was able to create an ideological foundation that united a Christian tradition of asceticism with his hardening sports training as part of the creation of a new ethical human type. Muller came from a family of ministers, studied theology and was himself destined for a clerical career. On the one hand, his work appeared to represent a break with the Christian Protestantism when he in his youth engaged in the body worship of early modern sports in Copenhagen in the late nineteenth century. On the other hand, the hard training he subjected himself to in countless disciplines, could be interpreted as an expression of a form of continuation of Christian asceticism. For Muller, sport became a compromise between Christianity and the devotion to the body, which culminated in his book My System from 1904.

Muller was also one of the first and main Danish agitators for eugenics. In this he was explicitly inspired by an international tendency represented by such names as the Swedish author Ellen Key, who won international reputation with her two volumes entitled The Century of the Child (1900), by the British author H.G. Wells' Mankind in the Making (1906) and finally by the Dutch doctor and author J. Rutgers' book Raceforbedring (Improvement of Our Race) published in 1908. In 1908, Muller published the book Kønsmoral og livslykke (Sexual Morality and the Happy Life). In this book, he took a quite liberal position by arguing strongly against the Christian churches' sexual morality and for free contraception and the legitimacy of sex before marriage between two people who loved each other. ${ }^{55}$

In this book, however, Muller also proposed that municipal doctors should be authorised to prohibit "drunkards, epileptics and syphilitics" from having children. In the same way a clergyman ought to refuse to marry a "young and healthy bride" to an "alcoholic, tubercular or venereally infectious bridegroom." In addition, Muller interpreted homosexuality as an illness, and he proposed that gay men should not be allowed to enter the swimming facilities where they could be together with heterosexual men and boys. ${ }^{56}$ In Muller's opinion a sound society would emerge if all the people whose only mission in the world was to be "outcasts and noxious animals" were weeded out. Eugenics would mean an increase in the number of a class of people who were characterised as "healthy, strong, intelligent, good, clever, industrious and enduring." ${ }^{57}$ Muller's ideas on the improvement of the human stock led to an interest in all the things he believed were obstacles to human perfection. Having indicated the way to achieve a vital body, he included the care of the body in a project for improved social hygiene.

Muller's deliberations resulted in a vision of society where all the bad elements

\author{
53 Mangan (1981). \\ 54 J.P. Muller “Om Terrænløb,” Dansk Idrotsblad March 16, 1900. \\ 55 Muller (1908). \\ 56 Muller (1908).
}

57 Lars Henrik Schmidt and Jens Erik Kristensen, Lys, Luft og Renlighed: Den Moderne Socialhygiejnes Fødsel (Copenhagen: Akademiskt forlag, 2004), 110. 
had been purified away. The truth was that there was a surplus of one kind of people and a shortage of another kind: "For already now there are far too many sickly, unhealthy, feeble-minded, criminal, lazy and useless people." In Kønsmoral og livslykke he proposed that illness consultants or hygiene inspectors should be engaged in the Danish parishes, and that they should be entitled to prohibit "demonstrably harmful child-breeding. These parish hygienic experts would then "in return provide instruction on the avoidance of fertilization." ${ }^{88}$ All in all, the rational basis of Muller's combination of health and cleanliness is not to be denied, in as much as modern hygiene has made a great contribution to the disappearance of many disastrous illnesses. However, the achievements of modern hygiene were also used for the promotion of a much wider world view based on the idea of a rational, civilised and orderly life and even eugenics, to which the case of J.P. Muller testifies.

\section{Niels Bukh and masculine revolt}

Gymnastics and eroticism? I have no experience with or name for this. I mean, I can't combine these two words with each other. ${ }^{59}$

The Danish gymnastics pedagogue Niels Bukh (1880-1950), together with his performance teams of young gymnasts, became known as representatives of the people of Denmark. In terms of Danish popular culture of the countryside, Bukh and his gymnastics occupied a level equal to that achieved within the arts by Bournonville and the Royal Danish Ballet under Harald Lander's internationally renowned leadership from 1932. The acrobatic and powerful male body that Bukh promoted became a symbol of the Danish nation far beyond Denmark's national borders. Bukh showed his gymnastics to big audiences in remote settings as the Soviet Union, Manchuria, Korea and Japan in 1931, Brazil, Uruguay and Argentina in 1938, and South Africa in 1939. He also gave displays in the US in 1923, 1926, 1931 and 1939. Traditionally, gymnastics has been presented, not least in its Danish rural variant, as a relatively de-sexualised zone, complete with cold shower after training, where anxious parents might securely send their children far away from the temptations of the big city. But—as will be shown - gymnastics also had room for erotic, beckoning undercurrents.

Bukh's early years were the prototype of a childhood and adolescence in a Grundtvigian farming community. His childhood home was beside the school, Vallekilde Folk high school, where his father was a teacher. Niels and his brothers and sisters went to the small, newly established Grundtvigian independent school, where emphasis was placed on the joy of living, songs and 'the living word,' a Grundtvigian tradition for awakening and enlightening the farming communities through a language filled with images rather than the 'dead letters' from a culture written words.

As a young man, Niels Bukh for many years taught Lingian gymnastics to local associations, whereby he achieved a reputation through his springtime displays. Since Bukh's teams usually won, the various associations competed to get Niels Bukh as their trainer. The revolution in Niels Bukh's conception of gymnastics happened whilst training a young men's team in 1916 and 1917. Euphorically, he wrote to his

58 Muller (1908).

59 Niels Bukh in an interview, published in Berlingske Tidende, July 26, 1939. 
students about the development of a new form of gymnastics, which in contrast to Lingian gymnastics would be a demanding, working gymnastics that would radically change young men's bodies. At a later point, measurements of the burn-off of calories in Bukh's gymnastics showed that it was a highly intensive form of gymnastics, especially when compared to Lingian gymnastics, but also when compared to dance and running. ${ }^{60}$

Bukh did not believe that Lingian gymnastics was effective against true physical problems, such as those that marked young male farmers because of "the hard, often repetitive tasks they had to perform [...] The ordinary farm worker is stiff and bent in his back and shoulders, the muscles in his chest are short, those of his front are not suitable for work, and his hamstrings are too short, all a consequence of his hard labour, which early on makes him awkward and restricted in movement." ${ }^{\prime 1}$ Therefore, Bukh created his new so-called 'primitive' gymnastics (Figure 2). He deliberately chose the word "primitive" in order to emphasise the 'back to nature' or back to 'the natural body' elements of his programme. To combat the bodily stiffness of the young farm men, he applied techniques such as the so-called passive flexing. This was a form of stretching exercise in which one student would stretch out another's muscles and then push or press quickly and with great force. Niels Bukh's description of primitive gymnastics was: "One is seeking, in the quickest way possible, by strong rhythmic swings, flexing, twisting and stretching, passive or active [...] to get rid of stiffness, flabbiness and awkwardness." ${ }^{2}$

The dynamic, primitive gymnastics, with its muscular contact between men, comprised an entirely new gymnastics concept. Bukh's primitive gymnastics went beyond the focus on physical posture by Swedish gymnastics by emphasising the method's potential for achieving suppleness. Indeed, suppleness became the main avenue to a general straightening and unfolding of the body. On top of this, there was Bukh's display gymnastics, in which the men working in pairs lifted, pulled and supported each other. Put briefly, Bukh revolutionised men's movement, contact and dress forms. The male gymnasts performed at one and the same time delicate and powerful movements.

During Bukh's gymnastics training sessions, the floor could become wet with sweat, and, with the elite gymnasts, sweat could be sprayed onto those who stood behind anyone doing violent arm swings. ${ }^{63}$ The hard tempo made it impossible for muscles to become stiff while the exercise was underway. The gymnastics had a rhythmic, flowing character, and the practitioners' ability to give themselves wholly to the particular movement was fundamental.

The aim of the exercises was that the students, after several months of primitive gymnastics, would become so supple that they were qualified to begin practising display gymnastics, which Bukh preferred to call sports gymnastics. During the displays of primitive gymnastics, the male gymnasts were dressed only in an item known as the "little black," a type of boxer shorts inspired by the French gymnast educationist Georges Hébert (1875-1957), but shorter. The result was that Bukh's male gymnasts exposed their strong, well-trained, sweating and often sun-tanned torsos

60 Johannes Lindhard, Den specielle gymnastikteori (Copenhagen: Levin og Munksgaard, 1927), 110.

61 Ungdom og Idrcet, March and April 1916.

62 Bukh in Ollerup Højskoles Elevforening, Årsbog (Ollerup: s.n., 1917), 89.

63 Cf. interview with Bukh-gymnast W. Andersen. 
to the different audiences, which was an entirely new feature among adult men. The displays of sports gymnastics had the gymnasts dressed in white one-piece suits that were taken from Lingian gymnastics but made so tightly fitting that nothing regarding the genitals of the performers was left to the imagination, neither for Bukh nor for the spectators.

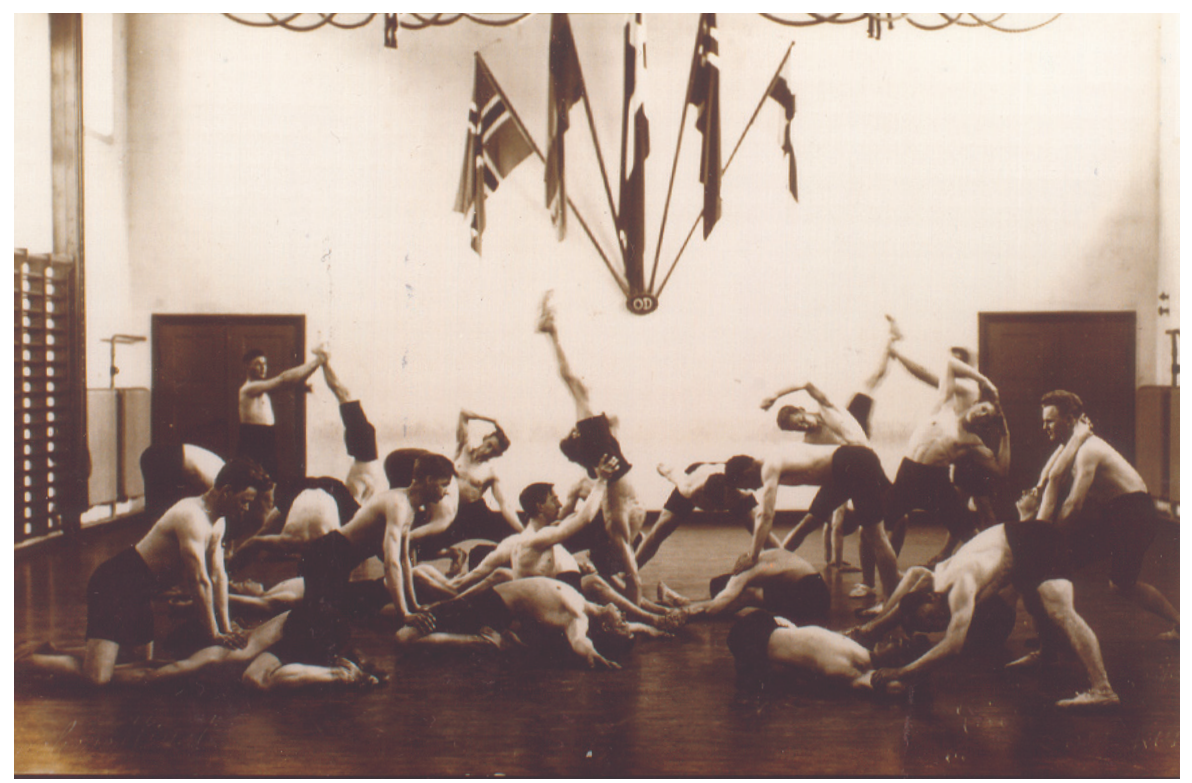

Figure 2. Niels Bukh's so-called primitive gymnastics with close body contact between the half nude young gymnasts in black boxer shorts. Source: Niels Bukh's archive at Ollerup Gymnastics high school.

Bukh's sports gymnastics was influenced by the Lingian system, but Niels Bukh had developed a series of new exercise forms, including the so-called "working in twos," where the exercise required the men to work in tandem. ${ }^{64}$ For an example, one gymnast might sit on the shoulders of another and slowly, almost in surrender, lean back with arms outstretched to both sides. Another central position was when two men stood side-by-side, bowed heads towards each other and with outstretched arms took hold of each other's hands, after which they bent away from each other letting their arms describe a circle for the audience. It was precisely the dual combination of a strong muscular masculinity and feminine rhythm and elegance in movement that comprised the core of Bukh's men's gymnastics. If the feminine element achieved a general acceptance, it was due to its being counterbalanced by a strong masculine quality. Due to Bukh's exploration of extremes, his gymnastics for men was at one and the same time both more masculine and more feminine than any previous Danish gymnastics.

For a section of young men, primitive gymnastics became a type of rebellion, which rejected the older Lingian male ideal, which was more static and physically weaker. In his manifesto Primitiv Gymnastik (1922), Bukh claimed to have fulfilled the Lingian ambition for gymnastics that was to create "young men as beautiful as

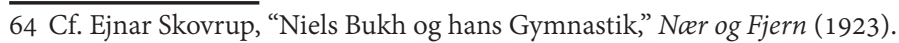


the Greeks and with manly character." ${ }^{\prime 5}$ Bukh's supporters maintained that the reason for the tough primitive gymnastics lay in the difference between the sexes. To quote one of Bukh's pupils, primitive gymnastics was "in every way an entirely real-man's gymnastics [...] It does not suit women or the weak, this is true. For them it would in every way be a 'gymnastics of torture"." 66

Bukh's male gymnasts were supposed to be masculinised by the training. The girls, as well as the boys, could have an eye for the young men's bodies. As one young girl gymnast said, "A lot of the 'country clods' got a 'nice shape' by doing Bukh's gymnastics, especially one young man that all the girls took a shine to." ${ }^{\prime 67}$ In this vein, a male elite gymnast from Niels Bukh's international team admitted the benefits: "We definitely had a certain advantage. But that's something I never went in for [...] but there were certainly some who made use of what they had." ${ }^{68}$

In summary, gymnastics became a forum where the young men and women could meet under presumably reassuring conditions, but at the same time gymnastics allowed the two sexes to get a closer look at each other's physical appearance at displays or at the parties held afterwards. Beyond this, Bukh's choice of dress for the gymnasts of both sexes was so tight-fitting that anyone so inclined would have a clear idea of what they were hoping to get involved with. With regard to the female gymnasts this was made even clearer during movement which clearly revealed the shape of their breasts.

\section{Love between men}

For some years until 1920 Bukh had a relationship, much resembling a marriage, with his former student Alfred Jørgensen, who apart from becoming the school's inspector was a trusted colleague and friend to the Gymnastics High School. It puzzled one of Bukh's nieces why there was a double bed in Uncle Niels's bedroom, and she asked her mother, Bukh's sister, Kirstine Bækhøj, why that was. The mother answered, according to the niece, that the bed was for Niels Bukh and a man, whom she called "Niels Bukh's wife." 69

Only few students knew of Bukh's sexual orientation. Although even Bukh tried to treat his homosexuality as an entirely closed subject, it is unthinkable that instructors at the gymnastics school were unaware of that side of Bukh's nature. Bukh's own mother and sister would tease him by calling him by the Danish girl's name of Ebba, taken from his middle name Ebbesen. ${ }^{70}$

Bukh's cultivation of a masculine aesthetic, the many classical Greek statues of naked male youths at the school and even in Bukh's private quarters, could indicate a quite positive relationship to his sexuality. Added to which is the fact that Bukh, at least until 1933, was not afraid of showing his affections for his partners in public and on school photographs.

One reason that Bukh was attracted by gymnastics was presumably because

65 Niels Bukh, Primitiv Gymnastik, (Ollerup: s.n., 1922).

66 Ungdom og Idroet, January 28, 1916.

67 Interview with Bukh-gymnast K.H. Gaardsted.

$68 \mathrm{Cf}$. interview with Bukh-gymnast H. Mortensen.

69 Interview with Bukh's niece E. Haastrup.

70 Interview with E. Haastrup's daughter. 
it provided him with a free space, where comradeship and a love of strong, wellformed young men could be pursued without raising suspicions of homosexuality. Moreover, we have evidence that he had relationships with his pupils. ${ }^{71}$ But bearing in mind the strict heterosexual moral norms of his time, his sexual orientation must have provided fertile soil for the anxiety of being discovered, which in one instance would have ruined his career as a gymnastics educationist, not the least since homosexuality was illegal until 1933 in Denmark on the charge of so-called sodomy.

Bukh's homosexuality likely played a role in his development of a new masculine aesthetic from 1916/17 in the field of gymnastics. It is hard to explain the development of Bukh's revolutionising gymnastics without taking into consideration his sexuality. As the sociologist Henning Beck puts it, homosexual men tend to cast a more direct glance at other men. ${ }^{72}$ Bukh undoubtedly experienced the male aesthetic differently from heterosexual men since he could also see men as objects of desire: and this helped him to evolve new and revolutionary men's exercises that were distinguished by both beauty and power, both masculinity and femininity.

There are striking similarities between Bukh's male aesthetics and the revolution in the inter-war period initiated by the likewise homosexual American dance choreographer Ted Shawn, who mainly selected his dancers from the universities and from sport. ${ }^{73}$ Furthermore, there can be observed a parallel between Bukh's relations with his male friends and partners - who often became his close junior colleagues as gymnastics teachers - and relations between homosexuals in ballet such as between the ballet impresario Diaghilev and the dancer Nijinskij.

Bukh did not feel totally restricted by his homosexuality but, on the contrary, had connections to other homosexuals and actually made his school a free zone for homosexual artists. This was especially evident at the so-called Nordic Olympics which Niels Bukh arranged in 1935 attended by 14,000 gymnasts, 40,000 spectators and the Danish royal family. ${ }^{74}$ Bukh collaborated, for instance, with the homosexual ballet dancer, Svend Aage Larsen, who was part of a show for 2,000 Danish spectators at the gymnastics high school in Ollerup prior to Bukh's participation in the Berlin Olympics in $1936 .{ }^{75}$

From a sociological point of view, the gender-divided sports culture in modern society can be interpreted as a space where homosexuality is repressed to a large degree.$^{76}$ If homosexuality were to become present as a conscious possibility, sport with the prevailing sexual norms would no longer in the same way be able to function as a space where heterosexual men, too, can touch each other and pursue a sense of close masculine comradeship, because homosexuality would threaten to sexualise the relationships. The possibility of close physical and psychological contact in sport makes it an obvious zone for homosexual men and women to be close to heterosexuals of their own gender but it might render it necessary that their homosexual

71 Hans Bonde, “Niels Bukh's Gymnastics School in Denmark, 1912-1933: Gymnastics, Erotics, and Male Bonding," International Journal of the History of Sport 32, no. 6 (2015), 800-14.

72 Henning Bech, When Men Meet: Homosexuality and Modernity (Cambridge: Polity Press, 1997).

73 Ted Shawn, Thirty-Three Years of American Dance (Pittsfield: Eagle Printing \& Binding Company, 1959).

74 Interview with Bukh's niece Inger Markvardsen.

75 Årskrift for Gymnastikhøjskolen (Ollerup: s.n., 1936).

76 Bech (1997). 
orientation remains undisclosed. ${ }^{77}$ Paradoxically, the taboos in rural Denmark made it easier for Bukh to keep his homosexuality concealed.

In the perspective of gymnastics, Bukh changed the stereotypical male expression in Ling rural Danish gymnastics from an almost military, relatively static and linear bodily expression in the direction of rhythmic movement and with a level of nudity and intimacy of the bodies that was until then unheard of in the Danish countryside. In doing so he made an important contribution to the personal emancipation of many young farming men. ${ }^{78}$ In the aesthetic history of masculinity, it has often been male homosexual aestheticians, designers, musicians, dancers and so on who have opened new avenues for the expression of male emotions, and this was also the trademark of Bukh's achievement. His gymnastics was even criticised for being too 'feminine, ${ }^{79}$ which was a dangerous criticism for Bukh, who had to hide his homosexuality.

\section{Bukh's relations with Nazi Germany}

Bukh was very keen on expressing Danish national sentiment by portraying gymnastics as a collective expression of the bodily excellence of the Danish "imagined community." ${ }^{\circ 0}$ He showed his gymnastics in many European countries, in USA and Canada, in Asian countries and in South Africa under the Danish flag, with Danish songs, H.C. Andersen story-telling and Danish folk dance, and in this endeavour he was actively supported by the Danish Foreign Service. ${ }^{81}$ However, he also flirted with National Socialism.

Bukh was very keen on experiencing Nazi Germany at first hand. In October 1933, he was invited to undertake a tour of Hungary and Austria with both a men's and a women's team, and he took the opportunity on both the outward-bound and the homeward journey to visit Berlin. On the trip home from Hungary, the troupe was invited by a section for physical education of the German national socialist teachers' federation to present a display in Berlin. On the day prior to the display, the troupe were shown around the city by a man from the German SA, who focused not least on the various mythical sites for German Nazism such as the Reichstag building, as well as the building being carried out for the coming Olympic Games in Berlin in $1936 .^{82}$

The German organisers gave Bukh a warm welcome, and must have known about Bukh's right wing political leanings. When his team entered a large gymnastics'stadium bearing the Danish flag, Dannebrog, they received a tumultuous reception from the around 3,000 uniformed spectators, primarily German Nazi teachers of physical education, giving 'Heil Hitler' salutes in traditional Nazi fashion. The display took place in the middle of the hall on a massive podium, surrounded by "young brown-shirted Nazis carrying swastika banners." ${ }^{83}$

77 A general introduction to the theme of "homoeroticism" in sport is given in Arnd Krüger, The International Politics of Sport in the Twentieth Century, eds. J Riordan and A Krüger (London: 1999), $191-216$.

78 Bonde (2015), 800-14.

79 Bonde (2015), 800-14.

80 Anderson (2006), 6.

81 Hans Bonde, "Nationalism in the Age of Extremes: Taking Danish Gymnastics to the World," International Journal of the History of Sport 26, no. 10 (2009), 1414-435.

82 Niels Bukh in Fyns Venstreblad, October 29, 1933.

83 Kristian Krogshede, Årsskrift for Gymnastikhøjskolen i Ollerup (Ollerup: s.n., 1933), 47-49. 
Returning to Denmark, Bukh was completely open about the process of forming a new set of opinions that this tour had instilled into his students. Bukh said that "[t]hose of my countrymen who, on the journey down, were not convinced about the order and capacity" that reigned in Germany became "certainly convinced by the return journey." Bukh described how he had been asked by a German border guard whether the newspaper Bukh had in his pocket contained mostly lies or the truth. Bukh "replied calmly 'mostly the truth,' since it carries Hitler's letter to the German people and his collected radio speeches." The students and Bukh read "Hitler's collected letters and radio broadcasts - a marvellous expression of an ideal and inspired coordination of home and foreign policy, and we, or at least I, felt that we stood before something here that was noble and true." ${ }^{84}$ Bukhs affinity for Nazi Germany was apparent for his contemporaries. The correspondent of the Conservative newspaper Nationaltidende, who was present at the display given in Berlin, sent out a press release that landed, on 20 October, on the front page of his paper in an article entitled "Niels Bukh is Denmark's Hitler - but he came into the world 20 years too early." 85

Bukh's position on Nazi Germany caused a press uproar in Denmark that should be evaluated in the light of the fact that Bukh provided a concrete occasion for a wider public discussion in Denmark about what was actually happening in Germany. The general groundswell caused by the Nazi seisure of power caused rumours to travel over the southern border about the true causes of the Reichstag fire, concentration camps, Germany's withdrawal from the League of Nations, the creation of a Danish committee to help refugee Jewish intellectuals - which included Albert Einstein - the pressure on Austria's Chancellor Dollfuss and the forthcoming 'election' in Germany (set for 12 November). On top of this, during the previous spring and summer period, a certain pressure had been applied to Denmark's southern border through excitable public remarks by Nazis from the South Schleswig region who had been animated by the Nazi takeover of power. Although the authorities in Berlin at this time had little intention of disturbing the otherwise friendly relations to a small 'Aryan' nation to the north over the rights to govern the North Schleswig region, the commotion created a very vigilant attitude-not least in South Jutland-towards the Nazi regime. ${ }^{86}$

The sharp criticism provoked a typical reaction from Bukh, who through a further radicalisation went on the offensive, and this time in an anti-Semitic direction as well. Towards the end of October, Niels Bukh submitted an account of "my view of the new Germany" to $12-14$ daily papers and periodicals. ${ }^{87}$ Bukh found it "hard for the many noble and valuable forces within the Jewish people, who must suffer in innocence" but if "such a gigantic task as the one undertaken by the new Germany be achieved at a fast pace" then:

84 Berlingske Aftenavis, October 28, 1933.

85 Nationaltidende, October 20, 1933.

86 Cf. Henrik Sandø Nissen, "Folkelighed og frihed 1933: Grundtvigianernes reaktion på modernisering, krise og nazisme," in Dansk identitetshistorie, vol. IV, ed. Ole Feldbæk (Copenhagen: C. A. Reitzels Forlag 1992), 607-15.

87 Berlingske Aftenavis, October 28, 1933. 
a distinction between the beneficial and less beneficial foreign elements was perhaps impossible, and unfortunate violence therefore difficult to completely avoid. It would have been different in a small nation where every person almost knows the other. If the new Germany requires all its damaging, foreign blood removed, then Germany must pay and bleed for it, but — trust in this—-the operation is necessary and the pain worth it. ${ }^{88}$

It might seem strange that Niels Bukh, a homosexual, could be an avid supporter of a system that would carry out the modern world's most barbaric assault on homosexuals and the elimination of a very strong homosexual culture that had existed in the large cities of the Weimar Republic. Bukh's 'visit' to Berlin took place, however, at a point when the Nazi terror against homosexuals was still in an embryonic state, and in the SA in particular there was a good deal of tolerance for homosexual friendships. But when Hitler liquidated the leaders of the SA in the so-called Röhmputsch, blaming them for a widespread homosexuality among the corps, this acted as a green light for further extremely violent persecutions of homosexuals. Bukh's visit occurred before that "night of the long knives," which took place on June 30, $1934 .{ }^{89}$ Bukh may therefore have gained the impression that Nazism had less of a homophobic attitude than it really had. Perhaps the Nazi pursuit of male fellowship gave Bukh the feeling that, here, he was not an outsider but an integrated part of the people's fellowship.

Bukh's impression of Nazism had, however, a basis in the ambiguity of the Nazi conception of relations between men. On the one side, these relations were held high. On the other side, they certainly led to persecution as soon as the relationship crossed over into homosexuality. ${ }^{90}$ The Nazi ideology contained a revolt against the cold, calculating relationships between men in bourgeois society. Instead, a strong feeling of loyalty, idealism and self-sacrifice was to be cultivated among groups of comrades, which was an essential building block for a military upbringing, and which was placed on a par with suitable historical all-male fellowships, such as the Knights Templars. Therefore, the Nazi hatred of the Freemasons fraternity should be seen against the background that it was regarded as a cosmopolitan, liberal, instrumental and class-divided bourgeois organisation, and it was in competition with the Nazi idea of Männerbund, or a league of men, such as the SS and the SA. The artist Josef Thorak was most instrumental in the visual mediation of heroic comradeship in the Third Reich. ${ }^{91}$

The notion of comradeship also played a crucial role in Bukh's gymnastics, not least in two men's intense collaboration in the very physically demanding and aesthetic working in pairs. To provide a symbol of comradeship, Bukh had a statue set

88 Berlingske Aftenavis, October 28, 1933.

89 Cf. the classic book on the persecution of homosexuals in Nazi Germany: Burkhard Jellonek, Homosexuelle unter dem Hakenkreuz (Paderborn: Verlag Schöningh, 1990), 95-100.

90 Klaus Theweleit indicates this opposition in his book Männerphantasien (Frankfurt: Verlag Roter Stern, 1977), 61-66. However, we know very little about men as a specific category in Nazi society. An attempt has been made, though, in Michael Burleig and Wolfgang Wippermann "Men in the Third Reich," in The Racial State: Germany 1933-1945, ed. Michael Burleig and Wolfgang Wippermann, (Cambridge: Cambridge University Press, 1991), 267-303.

91 Cf. Bent Fausing, Steffen Kiselberg and Niels Senius Clausen, Billeder af mæendenes historie (Copenhagen: Tiderne Skifter, 1984), 116-19. 
up in 1937, called fellowship, which according to Bukh portrayed "two young men hurrying forward. The one has momentarily stumbled but the other stretches out a helping hand, while he continues to point forward towards the goal that they both struggle to attain." 92

Nazism's selection of a strongly anti-homosexual profile led to internal problems within the Nazi party-an organisation built up around men spending a great deal of time around each other, separated from women and children and, with the enormous priority set for sports and paramilitary training, in constant close physical contact with one another. Levels of homophobia and anti-homosexual legislation was constantly increased, almost as a form of pre-empted defence against fears that Nazi fellowships might have some elements of homosexuality about them. Nazism's entire approach to male solidarity was also responsible for the much tougher regulations against male homosexuality than the regulations against lesbianism.

If the Nazis did draw up such a brutal policy towards homosexuality, it might have something to do with the fact that, in the first years of Nazi government, the widespread point of criticism in the anti-Nazi press against the Männerbund was that these leagues of men were based on homosexuality. With the murder of Röhm in 1934, the coupling of Nazism with homosexuality became less frequent in the German anti-Nazi press in exile. ${ }^{93}$

In Danish Labour circles there was so much indignation at Bukh's agitation on behalf of the Third Reich that it was decided untraditional means would be required. In the first instance, a group consisting of three newspaper journalists from the Labour press started investigating Bukh on Funen, doubtless in the hope that they could show that Bukh practised political propaganda at his high school. But they found something far more piquant. As part of the general polemic, the Labour newspaper Socialdemokraten had "received a series of notifications" with compromising material concerning Niels Bukh. ${ }^{94}$ In short, they discovered that Bukh was homosexual and started to blackmail him politically to make him abstain from Nazi propaganda.

Bukh was under inhumane pressure and, because of the measures taken by the Labour figures including the Social Democratic Minister of Education, Frederik Borgbjerg, it would seem that a political hold on Bukh was established. Given that one of the proponents of the hard option, H.P. Sørensen, was editor-in-chief of the newspaper Socialdemokraten right up to 1941, there is no doubt that the paper continued in its strong desire to hinder Bukh's political agitation. On several occasions Socialdemokraten went in hard against Bukh, who was clearly affected by the criticisms.

After the Labour restraints were applied, Bukh did not altogether renounce his opinions of the Third Reich in public, but he did put a strong curb on them. However, after some years Bukh felt confident enough to take up his relations with Nazi Germany again. The Nazi authorities on the other hand were so pleased with Bukh that they invited him to present displays in the Third Reich, rushed off to Bukh's

92 Niels Bukh, Årsskrift for Gymnastikhøjskolen i Ollerup (Ollerup: s.n., 1937), 119.

93 Alexander Zinn, Die soziale Konstruktion des Homosexuellen Nationalsozialisten (Frankfurt: Peter Lang Verlag, 1998), passim.

94 Letter from H.P. Sørensen to Borgbjerg November 7, 1933, Privatarkiv nr. 37, Undervisningsministeriets gruppeordnede sager, Rigsarkivet. 
little cult refuge in the North and introduced his gymnastics into German sports education. For the Nazis, Bukh's gymnasts were the incarnation of a perfection of the Aryan race.

During the German occupation of Denmark Bukh had hopes for the creation of a European bloc, based on a German victory, up until the spring of 1943. He laid plans for a Danish youth federation and a Danish labour service that could well have posed a threat to Danish democracy, given his pro-German attitudes. He entered negotiations - without the knowledge of the Danish government-with the head of the German Reichsarbeitsdienst for the introduction of a Danish labour service in April 1942. And we know, too, that he laid plans for a world rally in celebration of peace, to be staged after the expected German victory.

Bukh's vision was nothing less than to turn Ollerup and Denmark into a world centre for physical education and training. This was why he built on a large scale that horrified even his own architect. In the event of a German victory, all evidence indicates that Germany's little Aryan-cult centre in the North would have had an important role in the newly re-organised European culture. The struggle for control of the youth of Denmark would have had an entirely different outcome. ${ }^{95}$

Though Bukh definitely had a great affinity with the totalitarian states, it should be remembered that he also gained recognition in democratic societies, which has not been the topic here. As a sole example, his tour of Great Britain in February 1937 may be mentioned. In the Royal Albert Hall two separate displays with orchestral music were sold out and presented to a public of around 7,500 spectators. According to The Observer, the young farm-lads made the Royal Albert Hall "boil over with excitement." ${ }^{\prime 96}$

All in all, the great paradox of Bukh's life is that he created a liberating male gymnastics that made the young men rhythmic and bodily audacious but in the end he tried to use it for totalitarian purposes. According to the chief architect for the Third Reich, Albert Speer, Hitler the former (failed) painter understood himself in the role of an artist much more than in that of a politician. And Nazism's enormous gravitational pull stemmed from a damnably competent aestheticisation of politics. Without a realisation of the power that a cult exerts, it is impossible to understand, let alone resist the appeal of Nazism to the human subconscious. Bukh was a master at playing on exactly these emotional strings. In this way his attempt to contribute his gymnastics to Danish national identity became a dangerous leaning towards a National Socialist interpretation.

\section{Conclusion and comparison}

The article has focused on the latent erotic dimensions of gymnastics which offer new inspiration to international research. It is remarkable that Denmark has produced two gymnastics educators with international impact who followed each other chronologically. Even more remarkable is the fact that both their systems had international ramifications, not least when it comes to the culture of masculinity through Bukh's many international displays and Muller's displays in Europe and the publication of his book My System in 1.5 million copies.

95 Hans Bonde, "The Struggle for Danish Youth: Fascism, Sport, Democracy," International Journal of the History of Sport, 26, no. 10 (2009), 1453-454.

96 Bonde (2009). 
Of course Muller's and Bukh's erotic gymnastics systems did not emerge out of the blue. Muller turned his inspiration from the German Life Reform-movement into a very practical guide to daily exercise whereby he could bring central ideas of nakedness and "naturalness" out to the world at an until then unprecedented scale. Similarly, he created a transformation of core values of his other source of inspiration, the founder of modern bodybuilding, Eugene Sandow. Whereas Sandow praised the muscular development of the body, Muller focused on the clean skin and the training of the inner organs as a source of health. Niels Bukh was likewise in his celebration of the nakedness of young gymnastic men inspired by the French educationist Hébert and in his praise of rhythmic and plastic movements by the Finnish gymnastics teacher Elli Björkstén.

Today we speak of "the sexual revolution" as something that happened from about 1968 onwards, but it is obvious from the example of J.P. Muller and Niels Bukh alone that the first decisive change to the gendered male role did not come in our own times. There have been many revolts against prevailing sexual norms since the end of the Victorian era. It is evident that gymnastics has given the cultivation of nudity, touching and free movements in the Foucauldian sense an innocent touch that paved the way for an erotic liberation. The stories of Muller and Bukh hereby confirm the thesis of Allen Guttmann that sport from the end of the nineteenth century and onwards has worked as a catalyst in the erotic field.

Muller created an amalgamation of on the one hand ascetic training and hardening of the body and on the other the erotic pleasure of nudity and self-touching. In this way Muller succeeded in creating his own synthesis of Protestantism and libertinism. Niels Bukh was like Muller raised in a Protestant home, although his upbringing was influenced by the brighter and more optimistic Grundtvigian variant. Ling gymnastic formed an important part of his childhood and youth, and from 1916/17 he used his phenomenal capabilities to create a new sweat-giving, rhythmic and aesthetic gymnastics that dressed the young, muscularly-defined men in only boxer shorts. Although he maintained his original protestant Christian believes and made the pupils and staff regularly attend sermons in the nearby church, he nevertheless launched a daring form of gymnastics that broke with all core concepts of the body in traditional versions of Protestantism. However, to Bukh this did not seem to pose a discrepancy.

Whereas Muller propagated his gymnastics as heterosexual and would exclude homosexuals from nude culture facilities, Niels Bukh as a homosexual could use his aestheticising glance at the young men to create totally new and beautiful choreographies just as the American ballet choreographer Ted Shawn did in the same period with his young male dancers. Besides the difference in the understanding of sexuality between Muller and Bukh, there was also the difference in time, since homosexuality was decriminalised in 1933 and Bukh thereafter lived in a more tolerant Danish culture than Muller.

Despite the fact that Muller and Bukh agreed on the importance of gymnastics in order to improve humanity there were significant differences between them. Muller hailed the individual through his home gymnastics while Bukh paid tribute to a group of young people though increasingly under the leadership of the great leader. Muller appealed to the urban population, while Bukh had his base in the countryside. Muller praised health through a comprehensive external and internal cleansing 
of the body, whereas Bukh paid tribute to beauty. Muller worshipped skin as man's most important organ, while Bukh celebrated the flexibility of the body. Whereas Muller was a cosmopolite that addressed people of all nations, Bukh was more nationally oriented in his creation of a scheme of gymnastics that was interpreted as particularly Danish and rounded by Danish rural culture.

Bukh's nationalistic sentiments eventually became so extreme that he moved from an extreme right wing position towards a genuine veneration of National Socialism. In fact, J.P. Muller despite being contrary to Nazi ideology, flirted with eugenics, however not in the Nazi racial version in which people of a foreign race should be prevented from reproducing or worse.

The development from Muller to Bukh also reflected the general development in society where Muller's optimistic faith in the emancipation of the enlightened individual from disease and suffering before the outbreak of the Great War was replaced by Bukh's dreams about the robust collective that eventually culminated in the 1930's uniformity and veneration of the strong man. However, both of them contributed to the dissemination of the ideal of a relatively liberated and undressed body: Muller through the tireless performances on European soil and the sale of millions of his books, Bukh through displaying his ideas by traveling with his team of gymnasts across the globe. 


\section{References}

Anderson, Benedict. Imagined Communities: Reflections on the Origin and Spread of Nationalism. London: Verso, 2006.

Anderson, Mark. Kafka's Clothes: Ornament and Aestheticism in the Habsburg Fin de Siècle. Oxford: Oxford University Press, 1995.

Årskrift for Gymnastikhøjskolen. Ollerup: s.n., 1936.

Bech, Henning. When Men Meet: Homosexuality and Modernity. Cambridge: Polity Press, 1997.

Berlingske Aftenavis (1933).

Berlingske Tidende (1939).

Bonde, Hans. "Den sportslige askese: Om den protestantiske etik og sportens ånd." Fønix 26, no. 3 (2002), 167-74.

Bonde, Hans. "Nationalism in the Age of Extremes: Taking Danish Gymnastics to the World." International Journal of the History of Sport 26, no. 10 (2009), 1414-435.

Bonde, Hans. "From Hygiene to Salvation: J.P. Muller, International Advocate of Gymnastics." International Journal of the History of Sport 26, no. 10 (2009), 1357-375.

Bonde, Hans. "The struggle for Danish Youth: Fascism, Sport, Democracy." International Journal of the History of Sport 26, no. 10 (2009), 1436-457.

Bonde, Hans. "The Time and Speed Ideology: 19th Century Industrialisation and Sport." International Journal of the History of Sport 26, no. 10 (2009), 1315-334.

Bonde, Hans. "Vitalist Sport." In The Spirit of Vitalism: Health, Beauty and Strength in Danish Art, 1890-1940, edited by G. Hvidberg Hansen and G. Oelsner, 88105. Copenhagen: Museum Tusculanum Press, 2011.

Bonde, Hans. "Niels Bukh's Gymnastics School in Denmark, 1912-1933: Gymnastics, Erotics, and Male Bonding." International Journal of the History of Sport 32, no. 6 (2015), 800-14.

Bukh, Niels. Primitiv Gymnastik, Ollerup: s.n., 1922.

Bukh, Niels. Årsskrift for Gymnastikhøjskolen i Ollerup (Ollerup: s.n., 1937).

Burleig, Michael and Wolfgang Wippermann, "Men in the Third Reich." In The Racial State: Germany 1933-1945, edited by Michael Burleigh and Wolfgang Wippermann, 267-303. Cambridge: Cambridge University Press, 1991

Chapman, David. Sandow the Magnificent. Urbana: University of Illinois, 1994

Cicurel, Inbal, and Rachel Sharaby. "Women in the Menstruation Huts: Variations in Preserving Purification Customs among Ethiopian Immigrants." Journal of Feminist Studies in Religion 23, no. 2 (2007), 69-84.

Collingham, Elisabeth. Imperial Bodies: The Physical Existence of the Raj, c. 18001947. Cambridge: Polity Press, 2001.

Corbin, Alain. The Foul and the Fragrant: Odor and the French Social Imagination. Cambridge: Harvard University Press, 1986.

Dansk biografisk håndleksikon. Copenhagen: Gyldendals Boghandel and Nordisk, 1923.

Defrance, Jacques. L'excellence Corporelle: La Formation des Activités Physiques et Sportives Modernes (1770-1914). Rennes: Presses universitaires de Rennes, 1987.

Elias, Norbert. The Civilizing Process, Vol. I: The History of Manners. Oxford: Blackwell 1969.

Elias, Norbert. The Civilizing Process, Vol. II: State Formation and Civilization. Oxford: Blackwell, 1982. 
Fausing, Bent, Steffen Kiselberg and Niels Senius Clausen. Billeder af mondenes historie. Copenhagen: Tiderne Skifter, 1984.

Foucault, Michel. The History of Sexuality, Vol. 1. London: Allen Lane, 1976.

Fyns Venstreblad (1933).

Guttmann, Allen. The Erotic in Sport. Columbia: University Press, 1996.

Jellonek, Burkhard. Homosexuelle unter dem Hakenkreuz. Paderborn: Verlag Schöningh, 1990.

Jensen, Johannes V. ”Tilegnelse." Skovene. Copenhagen: s.n., 1904.

Katholische Schulzeitung (1905).

Koch, Lene. Racehygiejne i Danmark 1920-56. Copenhagen: Gyldendal, 1996.

Krogshede, Kristian. Arsskrift for Gymnastikhøjskolen i Ollerup. Ollerup: s.n., 1933.

Krüger, Arnd. "The Homosexual and Homoerotic in Sport." In The International Politics of Sports in the 20th Century, edited by J. Riordan and A. Krüger, 191-216. London: Spon, 1999.

Lindhard, Johannes. Den specielle gymnastikteori. Copenhagen: Levin and Munksgaard, 1927.

Lindroth, Jan. Ling - från storhet till upplösning: Studier i svensk gymnastikhistoria 1800-1950. Stockholm: 2004.

Mangan, James Anthony. Athleticism in the Victorian and Edwardian Public School. Cambridge: Cambridge University Press, 1981.

Muller, J.P. “Om Terrænløb.” Dansk Idrcetsblad March 16, 1900.

Muller, J.P. Mit System. Copenhagen: Jul. Gjellerups Forlag, 1904.

Muller, J.P. My System. Translated by G.M Fox-Davies. London and Copenhagen: Tillge's Boghandel, 1905.

Muller, J.P. Vink om Sundhedsrøgt og Idroet. Copenhagen: Forlaget Tillge’s Boghandel, 1907.

Muller, J.P. Kønsmoral og livslykke. Copenhagen: s.n., 1908.

Muller, J.P. My Breathing System. London: s.n., 1914.

Muller, J.P. My Army and Navy System of Free-Standing Exercises: A Manual of Physical Training for Soldiers, Sailors, Constables and Others. London: s.n., 1915.

Muller, J.P. My System for Ladies: Fifteen Minutes' Exercise a Day for Health's Sake. Philadelphia: D. McKay, 1915.

Muller, J.P. The Daily Five Minutes. London: s.n., 1923.

Muller, J.P. What is Wrong with the Physical Education of our Children. Copenhagen: s.n., 1927.

Muller, J.P. My Sun-Bathing and Fresh-Air System. London: Athletic Publications, 1927.

Muller, J.P. Mit System for Småbørn. Copenhagen: s.n., 1928.

Muller, J.P. Mirakel-Kure. Copenhagen: s.n., 1934.

Nationaltidende (1933).

Nissen, Henrik Sandø. "Folkelighed og frihed 1933: Grundtvigianernes reaktion på modernisering, krise og nazisme." In Dansk identitetshistorie, vol. IV, edited by Ole Feldbæk, 607-15. Copenhagen: C. A. Reitzels Forlag, 1992.

Ollerup Højskoles Elevforening, Årsbog. Ollerup: s.n., 1917.

Poulsen, Anne Lykke. Den kvindelige kvinde. Copenhagen: Institut for Idræt, Københavns Universitet, 2005.

Sørensen H.P., letter to Borgbjerg, November 7, 1933. Privatarkiv nr. 37. Undervisningsministeriets gruppeordnede sager. Rigsarkivet. 
Rothschuh, Karl. "From the History of the Naturopathic Movement (VII): Healing Power of Light, Air and Earth: Arnold Rikli, Adolf Just and Pastor Felke." Zeitschrift für Allgemeinmedizin 16 (1983), 933-40.

Sadolin, Frode. Gymnastik i hjemmet. Copenhagen: s.n., 1904.

Schmidt, Lars Henrik and Jens Erik Kristensen. Lys, Luft og Renlighed: Den Moderne Socialhygiejnes Fødsel. Copenhagen: Akademiskt forlag, 2004.

Schoug, Frederik. Intima samhällsvisioner. Stockholm: Symposion, 1997.

Shawn, Ted. Thirty-Three Years of American Dance, 1927-1959. Pittsfield: Eagle Printing \& Binding Company, 1959.

Skovrup, Ejnar. "Niels Bukh og hans Gymnastik." Noer og Fjern (1923).

Steorn, Patrick. Nakna män: Maskulinitet och kreativitet i svensk bildkultur 19001915. Stockholm: Norstedts Akademiska Förlag, 2006.

Theweleit, Klaus. Männerphantasien. Frankfurt: Verlag Roter Stern, 1977.

Thing, Lone Friis. Sport - en emotionel affeere: Kvinder, holdsport og aggression. Copenhagen: Copenhagen University, 1999.

Thisted Amtavis (1939).

Ungdom og Idrcet (1916).

Vigarello, Georges. Concepts of Cleanliness: Changing Attitudes in France since the Middle Ages. Cambridge: Cambridge University Press, 1988.

Weber, Max. The Protestant Ethic and the Spirit of Capitalism. London and Boston: Unwin Hyman, 1930.

Zinn, Alexander. Die soziale Konstruktion des Homosexuellen Nationalsozialisten. Frankfurt: Peter Lang Verlag, 1998.

\section{Interviews}

54 interviews with people with firsthand experience from Niels Bukh and the gymnastics high school in Ollerup have been conducted between 1992 and 2000. The raw material is preserved at Department of Nutrition, Exercise and Sports in Copenhagen. 